\title{
Comparative Study of Variability of Formic Acid and Acetic Acid in the Atmosphere of the Humid Savannah of Lamto in Côte d'Ivoire and Djougou in Benin
}

\author{
Pêlèmayo R. Tourée ${ }^{1, *}$, Georges K. Kouadio ${ }^{1,2}$, Urbain K. Koffi ${ }^{1,2}$, Véronique Yoboué ${ }^{1}$ \\ ${ }^{1}$ Laboratory of Atmospheric Physics and Fluid Mechanics (LAPA-MF), Félix Houphouet Boigny University, Côte d'Ivoire \\ ${ }^{2}$ Physical Science Laboratory, Ecole Normale Supérieure, Côte d'Ivoire
}

Copyright $\bigcirc 2017$ by authors, all rights reserved. Authors agree that this article remains permanently open access under the terms of the Creative Commons Attribution License 4.0 International License

\begin{abstract}
From January 2005 to December 2009, a total of 457 and 444 samples were collected respectively rains in humid savannas of Djougou and Lamto. Using Henry's law, we determined the content in the air of the major organic monoacid ( $\mathrm{HCOOH}$ and $\mathrm{CH}_{3} \mathrm{COOH}$ ) from their concentration in rainwater. At Lamto, annual partial pressure of formic acid (FA) and acetic acid (AA) on the five year study is very little variable. It covers a range of $0.1 \mathrm{ppbv}$ and $0.2 \mathrm{ppb}$ to 0.4 to $0.7 \mathrm{ppbv}$ respectively for formic acid (FA) and acetic acid (AA). While in Djougou, it is very variable. It varies from 0.01 to $0.19 \mathrm{ppbv}$ to formic acid (FA) and 0.04 to 0.54 ppbv to acetic acid (FA). For both stations, it is a two times higher in the dry season than the wet season factor. This difference is related to the enrichment of a monoacid organic acid content in the air by supplying various sources of these acids. However, the correlation analysis that enables the production of formic acid (FA) and acetic acid (AA) Djougou like Lamto is not related to the marine source although the latter is close to the Gulf of Guinea.
\end{abstract}

Keywords Formic Acid, Acetic Acid, Variability, Humid Savannah

\section{Introduction}

Since the Conferences of Dublin, Rio and Johannesburg on Environment, the investigations on climate change and knowledge of the quality of atmospheric inputs is one of the major concerns of the global scientific community. In the atmospheric chemistry investigation, numerous studies showed Carboxylic acids are important and ubiquitous chemical constituents in all biogeochemical compartments like soil, hydrosphere, biosphere and the global atmosphere [1-4]. They contribute a large fraction to the atmospheric mixture of volatile organic compounds (VOC) [5-7]. Formic acid (FA) and acetic acid (AA) are usually the dominant species found in the highest mixing ratios, though other organic acid species have been observed [8-17]. General sources of carboxylic acids have been identified but a satisfactory source attribution is lacking to explain atmospheric observations [2]. FA and AA are emitted to the atmosphere directly from biogenic activities [18], especially vegetation [19-21] and combustion of fossil fuels or biomass [20], [22-25]. The oxidation of Volatile organic compounds (VOC), and in particular their ozonolysis has been suggested to be a secondary major source of FA and AA [26-30]. Ocean sources of these acids have been suggested by Baboukas et al. [31]. Recent studies showed biofuel combustion is non-negligible primary and secondary emission source of FA and $\mathrm{AA}$ in the atmosphere $[30,32]$.

FA and AA measurement methods are numerous and various (e.g., Mist chamber technique [33-35], embedded measurement devices in balloons [36], in the free troposphere by aircraft measurements [22, 37, 38] etc.). All these measurement methods are more or less complex and require a lot of logistical and financial resources for their implementation. For this reason there are few earlier studies over Africa on these acids in the gaseous phase [25]. However, as part of the IGBP-IGAC program (International Geosphere Biosphere Programme-International Global Atmospheric Chemistry), the African part of this network is controlled by the IDAF network (IGAC / DEBITS / AFRICA), the studies on rain chemistry in different ecosystem continent have shown that FA and AA are organic acids predominantly present in precipitation [39-42]. They contribute more than $50 \%$ to the total free acidity of rainwater in these regions [39-42]. This work is therefore a contribution to the understanding of the variability of the levels of FA and AA in the air of the atmosphere of the different ecosystems of the African continent, particularly in the air in the boundary layer of West Africa humid Savannah regions very little influenced by human activities. Thus, the 
aim of this study is to estimate for our two sites Djougou (Benin) and Lamto (Cote d'Ivoire), the levels of FA and AA in the air from their concentrations in the rainwater and to analyze their evolution in different time scale (monthly, seasonal and inter-annual) in the air of boundary layer. We have used Henry's law for the estimation. The results obtained will be compared in order to show and explain the differences which can exist between our two sites Djougou and Lamto

\section{Materials and Methods}

\subsection{Experimental Sites}

\subsubsection{The Djougou Site}

Djougou is a village situated in Northwest Benin. The IDAF site is located in Nangatchori $\left(9^{\prime} 65^{\circ} \mathrm{N}, 1^{\prime} 74^{\circ} \mathrm{E}\right)$ near Djougou, approximately $460 \mathrm{~km}$ from Cotonou (Figure 1). It has an average altitude of $438 \mathrm{~m}$. The site is one of the (three) meso-scale study sites AMMA (African Monsoon Multidisciplinary Analysis) (the site of Ouémé). This new site IDAF was also initiated within the framework of long-term observation period (LOP) AMMA in 2005. The site is located in a clearing surrounded by secondary forests, crops and fallow land, which has been subjected to burning (or burning) small-scale vegetation over the last five years. The IDAF Djougou site is located in vegetation zone of the southern Sudan, characterized by woodland. The climate is Sudano-Guinean with two seasons: a rainy season extends from April to October, about six months of rain and a dry season from mid-October to mid-April. The average annual rainfall is $1358 \mathrm{~mm}$ over the period $2005-2009$ (table 1). The daily mean temperatures vary from $25^{\circ} \mathrm{C}$ in August to $31^{\circ} \mathrm{C}$ in March. Daily amplitude of temperatures achieves $20^{\circ} \mathrm{C}$ during the Harmattan period (January) with minimum values from $16^{\circ} \mathrm{C}$ to $19^{\circ} \mathrm{C}$ to maximal are about $36^{\circ} \mathrm{C}$ to $39^{\circ} \mathrm{C}$. In August, the daily amplitude of temperatures is less marked with an order of magnitude around $5^{\circ} \mathrm{C}$ [42]. Vegetation is composed of a mosaic of dry forests and savannah, with dense and tall herbaceous strata, mainly composed of perennial grasses, and more or less dense woody strata. In the Global Land Cover Classification, our site is classified as deciduous open woodland [43, 44].

\subsubsection{The Lamto Station}

The second area study is the Lamto reserve of ecology and geophysics in Côte d'Ivoire. It covers an area of $2700 \mathrm{~km}^{2}$. The region of Lamto is part of group of Guinean savannah located approximately $160 \mathrm{~km}$ from the Atlantic Ocean, the Reserve precisely located at $16^{\circ} 21^{\prime} \mathrm{N}$ latitude and $5^{\circ} 02^{\prime} \mathrm{W}$ longitude (Figure 1) with an altitude ranging from 75 to $150 \mathrm{~m}$, the Lamto region enjoys a vegetation formed of two types of high-contrast landscapes; one hand high forest, dense, thick at the edge of the Bandama or trays and secondly with its grassy savanna dotted with vegetation cover palm trees and narrow creeks galleries which cut mosaic. Contrary to Djougou, the station of Lamto is part of the IDAF network since 1994. The climate in Lamto region is transitional kind between the equatorial climate and tropical climate that is to say the savanna; hot, humid and rainy with the possibility of four seasons can vary from year to year: the long dry season (December, January, February); the great rainy season that begins in March-April and lasts until July, the recession intra rainy August, and the small rainy season which falls between the rainy recession and the long dry season (mid-September to mid-November)[44,45]. The average annual rainfall on our study period is $1280 \mathrm{~mm}$ (table 1). At Lamto as Djougou; the seasons are schematically determined by the position of the Intertropical Convergence Zone (ITZC), the surface formed by the convergence of Saharan and oceanic air masses. The wet season starts when the position of the Intertropical Front reaches rather high latitudes. It allows the south air masses, loaded with moisture of the Atlantic Ocean, to move northward the Saharan hot and dry air masses. This moisture transport is a key factor for the monsoon system in West Africa [46, 47]. And the air relative humidity average oscillates between $50 \%$ and $88 \%$. With the installment of monsoon on West Africa, the months of June and July on both sites are the more wet months.

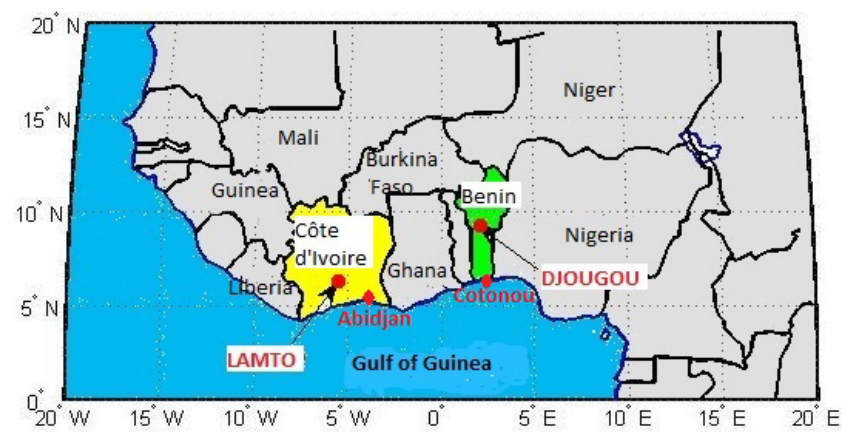

Figure 1. The Lamto (Côte d'Ivoire) and Djougou (Benin) sites location

Table 1. Annual precipitation (Pt in $\mathrm{mm}$ ) at Djougou and Lamto sites for the 2005-2009 periods

\begin{tabular}{|c|c|c|c|c|c|c|c|}
\hline \multicolumn{2}{|c|}{ Years } & 2005 & 2006 & 2007 & 2008 & 2009 & Mean \\
\hline \multirow{3}{*}{$\operatorname{Pt}(\mathrm{mm})$} & $\begin{array}{c}\text { DJOUG } \\
\text { OU }\end{array}$ & 1393.5 & 1143.5 & 1246.8 & 1372.4 & 1537.2 & 1338.7 \\
\cline { 2 - 9 } & LAMTO & 971.5 & 1257.5 & 11508.5 & 1211.4 & 1188.6 & 1227.5 \\
\hline
\end{tabular}




\subsection{Database}

\subsubsection{Sample Collection Procedure and Chemical Analyzes}

Like the other sites of the IDAF network the rains of Lamto and Djougou were collected using automatic collector. Inorganic $\left(\mathrm{Na}^{+}, \mathrm{K}^{+}, \mathrm{NH}_{4}{ }^{+}, \mathrm{Ca}^{2+}, \mathrm{Mg}^{2+}, \mathrm{NO}_{3}{ }^{-}, \mathrm{SO}_{4}{ }^{2-}, \mathrm{Cl}^{-}\right)$and organic contents of precipitation $\left(\mathrm{HCOOH}, \mathrm{CH}_{3} \mathrm{COOH}\right.$; $\mathrm{C}_{2} \mathrm{H}_{5} \mathrm{COOH} ; \quad \mathrm{C}_{2} \mathrm{O}_{4} \mathrm{H}_{2}$ ) were determined by Ion Chromatography (IC) in each rainfall event. $\mathrm{pH}$ is measured with an ATI Orion 350 instrument with a combined electrode (ATI Orion model 9252) filled with $\mathrm{KCl}(4 \mathrm{M})$ and saturated with $\mathrm{AgCl}$. The sample collection procedures and chemical analysis procedures of gases, aerosols and rains performed on each sites of IDAF observing system are in compliance with international standards for instrumentation, for collection protocols and analysis techniques implemented. They have been extensively described in previous studies [40-42], [48, 49] and are available at: http://idaf.sedoo.fr. The reliability of the results of ours analyzes is guaranteed by international standards provided by precipitation quality assurance program of the World Meteorological Organization (WMO). Results of these inter-comparisons are available under the reference 700106 at the following address: http://qasac-americas.org/. According to these WMO inter-comparison tests, analytical precision is estimated to be $5 \%$ or better for all ions, within the uncertainties on all measured values presented here.

\subsubsection{Determination of Partial Pressures $\left(\mathrm{P}_{\mathrm{gaz}}\right)$ in the Air}

During cloud formation, the partial pressure of organic monoacid $\left(\mathrm{HCOOH}\right.$ or $\left.\mathrm{CH}_{3} \mathrm{COOH}\right)$ in the air is balanced with the acid concentration on gaseous form present in the rainfall. The gas solubility balance in the aqueous phase of cloud droplet is governs by Henry law [19, 25, 50]. This law is given by:

$$
P_{i}=C_{S} / H
$$

where $\mathrm{P}_{\mathrm{i}}$ is the gas partial pressure ( $\mathrm{atm}$ ), $\mathrm{C}_{\mathrm{S}}$ is maximum concentration at saturation (mole/L) and $\mathrm{H}$ is the Henry's law constant ( mole/ L atm).

Considering the acid (AH):

$$
\mathrm{AH}+\mathrm{H}_{2} \mathrm{O} \underset{\leftarrow}{\stackrel{H_{3}}{ } \mathrm{O}^{+}+\mathrm{A}^{-}}
$$

The partial pressure $\mathrm{P}_{\text {gas }}$ of the each carboxylic monoacid in equilibrium with the water content of cloud is calculated by:

$$
\boldsymbol{P}_{g a z}=\frac{X}{H\left(1+10^{p H-p K a}\right)}
$$

where $\mathrm{P}_{\mathrm{gas}}$ is Gas partial pressure in the air (atm), $\mathrm{X}$ is the total concentration of the acid measured in the rainfall water (mole. $\left.\mathrm{L}^{-1}\right), \mathrm{H}$ is the Henry's law constant (mole. $\mathrm{L}^{-1} \cdot \mathrm{atm}^{-1}$ ), $\mathrm{pH}$ is the acidity of the rainfall sample and $\mathrm{pK}_{\mathrm{a}}$ is the $\mathrm{pH}$ at which half of the acid is dissociated.

\subsubsection{Determination of FA and AA Sources}

To identify the sources of formic acid and acetic acid, a statistical analysis (correlation and principal component analysis: PCA) of the chemical composition of rainwater has been made. A significant correlation coefficient $\alpha=0.01$ threshold between two ions may reflect the fact that these compounds have a common source or that they are partners in a common transport processes [51, 52]. To further discuss this aspect a representative item for each natural source has been selected. So we have $\mathrm{Cl}^{-}$for marine source, $\mathrm{Ca}^{2+}$ for terrigenous source, $\mathrm{K}^{+}$for biogenic source, $\mathrm{NH}_{4}{ }^{+}$for domestic fire or biogenic source and $\mathrm{C}_{2} \mathrm{O}_{4}{ }^{2-}$ for biomass burning source $[39,41,51,53]$.

\section{Results and Discussion}

\subsection{Analysis of FA and AA Sources}

The variation of contents of FA and AA in the atmosphere is related to the contribution of different emission sources. Thus research, potential sources of emissions of these two acids on our study sites proves to be of capital importance for the understanding and explanation of the differences of variation observed in our study.

In order to understand the variation of FA and $\mathrm{AA}$ in the atmosphere of boundary layer of our two sites, a statistical study: Principal component analysis and correlation coefficient calculation was made to identify the major sources of a year to another (table 1). On first glance, the analysis of the correlation matrix of Pearson's our two studies sites (Lamto and Djougou) showed strong significant correlation at the $1.00 \%$ between the two organic acids (formic and acetic acid) studied whatever the season and year ( $r$ between 0.70 and 0.83 ). This suggests a common source to both acids or they undergo the same process of incorporation into the cloud. On the other hand, it also notes that Lamto, oxalate, nitrate ion and two organic acids (FA and AA) exhibit strong correlations significant at the same level, regardless of the season and year. Indeed, we have respectively for FA and AA $\mathrm{r}$ coefficient values between 0.78 and 0.90 and between 0.78 and 0.80 on our entire study period. However, Djougou, nitrate ion, unlike oxalate shows no significant correlation with FA and AA, since the coefficients determined with these acids ranged between 0.47 and 0.58 , respectively, and between 0.50 and 0.62 . Furthermore, it is clear from this analysis that the calcium ion shows no significant correlation with FA and AA except in the dry season at Lamto where the coefficient is 0.70 and 0.77 respectively FA and AA. This assumes that the soils in the humid savanna of Lamto like those of Venezuela wet savannas are a natural source of FA and AA emission into the atmosphere of the region. However, later in our analysis this hypothesis was discarded since recent studies [21] have shown that the contribution of soils in the emission budget of these two acids at the boundary layer would be very negligible. Thus, this good significant correlation obtained is linked to the common process of incorporating of these acids 
and $\mathrm{Ca}^{2+}$ ions in the aqueous phase of the cloud. Finally, it is also interesting to note that the coefficients determined on our two sites (Djougou and Lamto) reveals no significant correlation at the 0.01 level between formic acid, acetic acid and $\mathrm{Cl}^{-}$and $\mathrm{Na}^{+}$. But emphasize the existence of significant correlation in Djougou as Lamto between the ammonium ion and formic and acetic acids. Therefore, we can infer that the biogenic source and domestic fires can be represented by the $\mathrm{NH}_{4}{ }^{+}$ion is a potential source of major organic acid in our study areas. However, despite the relative proximity of Lamto, with the Atlantic Ocean compared to Djougou, marine source virtually no part in the supply of organic acid in the air of the region.

To conclude this part of our study, it is interesting to indicate that the primary sources of FA and AA are the same for both study sites. These sources are therefore biogenic activities, vegetation, biomass burning and domestic fires. These sources will be added to photo-oxidation reactions and oxidation of precursors.

\subsection{Inter-annual Evolution of the Partial Pressures of FA and $\mathrm{AA}$}

The annual partial pressures average of FA and AA in the air at the boundary layer of humid savanna Lamto (Cote d'Ivoire) and Djougou (Benin) have been determined on the period 2005-2009 from the concentrations of these acids in water collected rain. At Lamto, the values are very few variable and cover a narrow range of $0.1 \mathrm{ppbv}$ to $0.2 \mathrm{ppbv}$ for FA and 0.4 to $0.7 \mathrm{ppb}$ to AA (Figure 3). The partial pressure average over the period of study was $0.14 \pm 0.04 \mathrm{ppb}$ with a coefficient of variation of $29 \%$ and $0.55 \pm 0.12 \mathrm{ppbv}$ to a coefficient of variation of $28 \%$ acid respectively FA and AA. However, in Djougou, the partial pressures of FA and AA are extremely variable. They cover values from 0.01 ppbv 0,19 ppbv in 2007 to 2005 for FA and 0.04 ppbv in 2007 to 0.54 ppbv in 2009 to AA (Figure 3). Thus, Djougou, the partial pressure average of FA is $0.098 \pm 0.062$ ppbv to a coefficient of variation of $63 \%$ and $\mathrm{AA}$ is that of $0.28 \pm 0.2 \mathrm{ppbv}$ with a coefficient of variation of $71.00 \%$. The variability of the acids in the atmosphere is due to the contribution of the major sources of emission [25, 39]. Our analysis showed the origin of these sources could be the photochemical oxidation of biogenic and anthropogenic volatile organic compounds (VOCs), vegetation and biomass burning. Thus, the variability of their contribution affects the variability of formic and acetic acids observed in both Lamto and Djougou. Moreover, the high coefficient of variation calculated in Djougou highlights that the mean contribution of these sources has a strong variation from year to year. However in Lamto, the year to year variability of this contribution of major sources is very weak, so the coefficient of the variation is low.

Table 2. Correlation coefficients between ions in rainwater. The 'Barvais' method was used with a $1 \%$

\begin{tabular}{|c|c|c|c|c|c|c|}
\hline \multirow{2}{*}{ Pairs of ions } & \multicolumn{3}{|c|}{ Lamto } & \multicolumn{3}{|c|}{ Djougou } \\
\hline & Dry season & Humid season & Annual & Dry season & Humid season & Annual \\
\hline $\mathrm{HCOO}^{-} / \mathrm{CH}_{3} \mathrm{CO}_{2}^{-}$ & 0.80 & 0.70 & 0.78 & 0.83 & 0.76 & 0.80 \\
\hline $\mathrm{HCOO}^{-} / \mathrm{NH}_{4}{ }^{+}$ & 0.85 & 0.83 & 0.86 & 0.72 & 0.68 & 0.74 \\
\hline $\mathrm{HCOO}^{-} / \mathrm{Cl}^{-}$ & 0.23 & 0.26 & 0.23 & 0.20 & 0.44 & 0.27 \\
\hline $\mathrm{HCOO}^{-} / \mathrm{Na}^{+}$ & 0.20 & 0.23 & 0.20 & 0.22 & 0.20 & 0.29 \\
\hline $\mathrm{HCOO}^{-} / \mathrm{Ca}^{2+}$ & 0.70 & 0.36 & 0.51 & 0.47 & 0.38 & 0.45 \\
\hline $\mathrm{HCOO}^{-} / \mathrm{K}^{+}$ & 0.24 & 0.23 & 0.29 & 0.35 & 0.33 & 0.47 \\
\hline $\mathrm{HCOO}^{-} / \mathrm{CO}_{4}{ }^{2-}$ & 0.90 & 0.78 & 0.87 & 0.86 & 0.81 & 0.80 \\
\hline $\mathrm{HCOO}^{-} / \mathrm{NO}_{3}{ }^{-}$ & 0.85 & 0.70 & 0.77 & 0.58 & 0.47 & 0.57 \\
\hline $\mathrm{CH}_{3} \mathrm{COO}^{-} / \mathrm{NH}_{4}^{+}$ & 0.78 & 0.73 & 0.79 & 0.74 & 0.73 & 0.73 \\
\hline $\mathrm{CH}_{3} \mathrm{COO}^{-} / \mathrm{Na}^{+}$ & 0.22 & 0.37 & 0.28 & 0.26 & 0.25 & 0.33 \\
\hline $\mathrm{CH}_{3} \mathrm{COO}^{-} / \mathrm{Ca}^{2+}$ & 0.77 & 0.37 & 0.60 & 0.55 & 0.41 & 0.49 \\
\hline $\mathrm{CH}_{3} \mathrm{COO}^{-} / \mathrm{K}^{+}$ & 0.56 & 0.59 & 0.59 & 0.2 & 0.37 & 0.48 \\
\hline $\mathrm{CH}_{3} \mathrm{COO}^{-} / \mathrm{CO}_{4}{ }^{2-}$ & 0.78 & 0.79 & 0.80 & 0.88 & 0.63 & 0.65 \\
\hline $\mathrm{CH}_{3} \mathrm{COO}^{-} / \mathrm{NO}_{3}^{-}$ & 0.82 & 0.65 & 0.70 & 0.62 & 0.50 & 0.56 \\
\hline
\end{tabular}



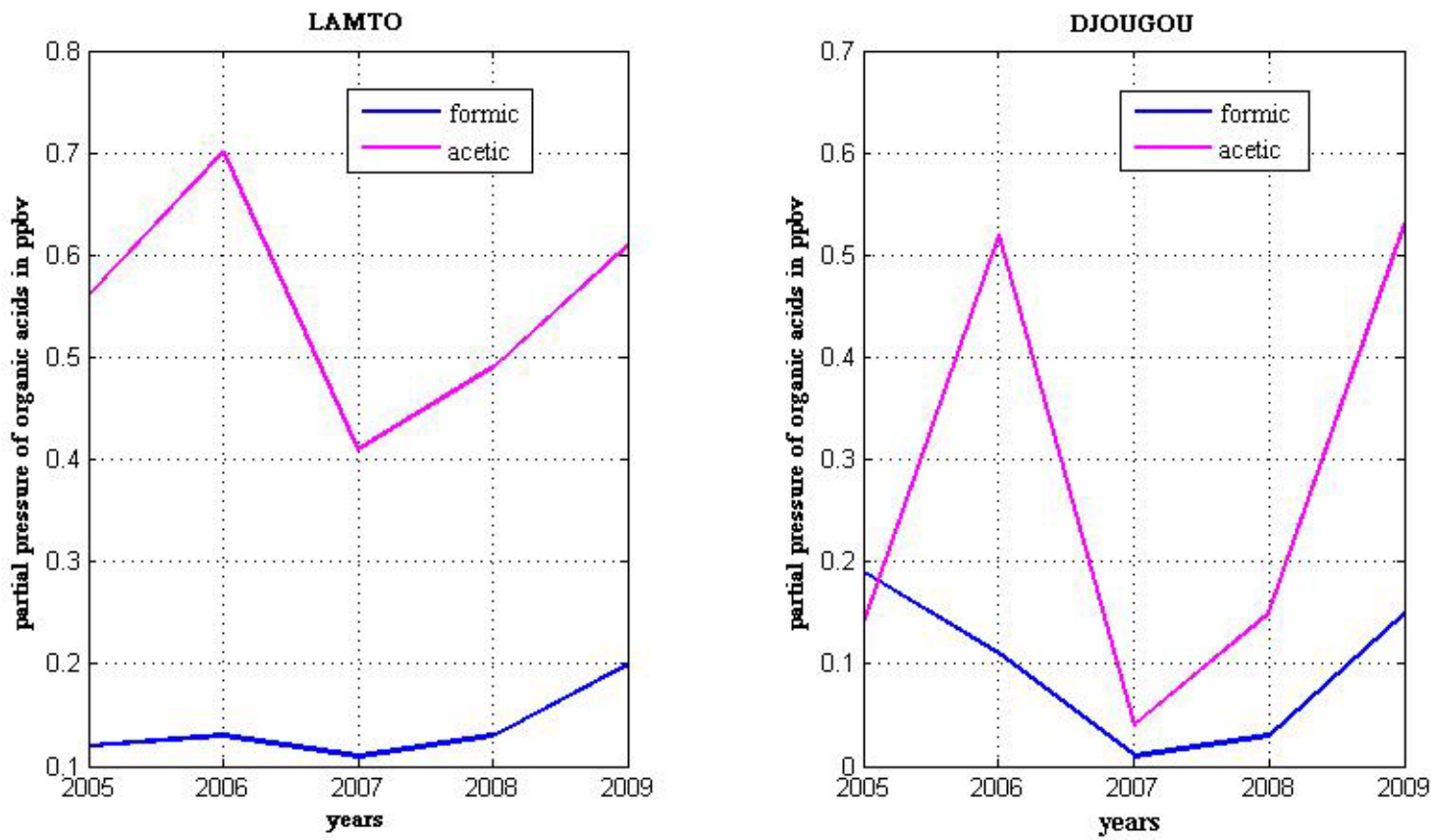

Figure 2. Inter-annual evolution of the partial pressures of formic acid and acetic acid at Lamto and at Djougou
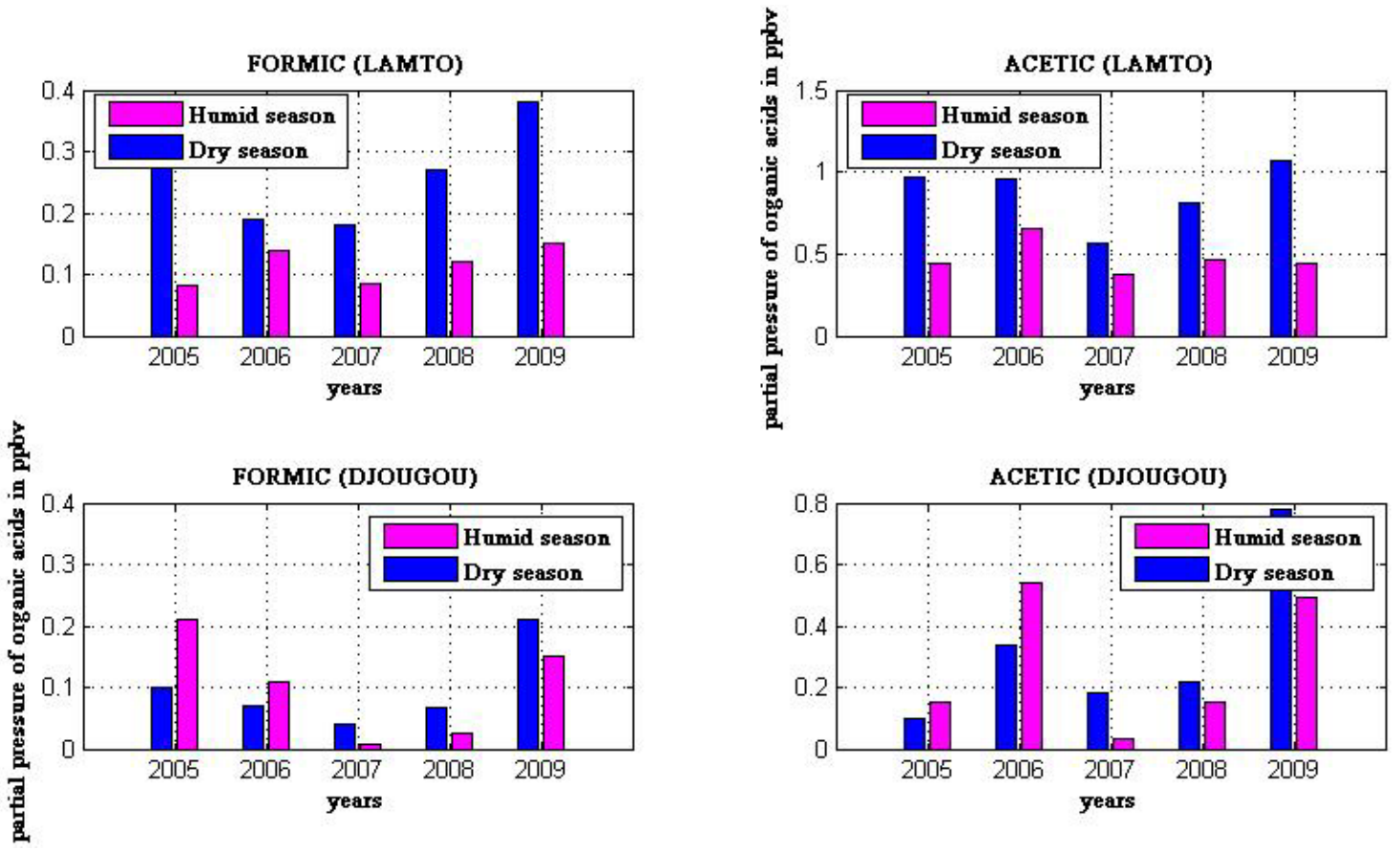

Figure 3. Seasonal evolution of the partial pressures of formic acid and acetic acid

The strong inter-annual variation of pressures rate in Djougou reflects highly variable inputs from sources of organic acids in region relative to Lamto. This high variability of contributions would be due to the proximity of agricultural activities in the region. The graphs also show that, at Lamto the partial pressures of FA and AA have similar interannual changes, but those of AA are averaged over the study period (2005-2009) two times higher than that of FA. Unlike Lamto, the partial pressures of two organic acids with Djougou showed similar trends as from only since
2006. In addition, with the exception of the period of 2006-2009, the partial pressure of FA is higher in 2005 by a factor of 1.6 than that of AA. The high content of FA relative to that of AA requires more input sources of this acid this year specifically. Although the major source of FA and AA are identical on the two study sites, the contents of the values of these two acids at Lamto are higher than Djougou. The low values obtained could be attributed either to a low intensity of acid sources during this period or to greater leaching of the atmosphere, especially during the humid 
season [25]. The influence of leaching on organic acid partial pressures depends on the solubility of the gas (acetic acid has a lower solubility than formic acid) and the amount of rain. Thus, the important rainfall level of Djougou comparing to that of Lamto over the study period allows us to say that this statement is partly due to significant leaching of the atmosphere at Djougou face to Lamto. Indeed, during the study period Lamto received an average of $100 \mathrm{~mm}$ of rain less than Djougou.

Moreover, the process of neutralization of acids can also be the cause of the low values observed in Djougou. numerous studies in Africa showed that, FA and AA contribution to the total free acidity of rainwater increases from the arid savannah of Sahel to tropical forest over this continent [40-42]. Indeed, Djougou's coordinates, particularly its latitude $9^{\circ} 42^{\prime} \mathrm{N}$ is a little closer to the Sahel region comparing to Lamto (latitude $6^{\circ} 21$ ). It is therefore more subject to the influence of air masses from the harmattan which are the source of a significant contribution of $\mathrm{Ca}^{2+}$ content in the particles wind in the form of gypsum $\left(\mathrm{CaSO}_{4}\right)$, calcite $\left(\mathrm{CaCO}_{3}\right)$ or dolomite $\left(\mathrm{CaMg}\left(\mathrm{CO}_{3}\right)\right.$ from soils of the Sahel and the Sahara Desert [41, 45, 49, 54]. Thus, acid neutralizing the phenomenon by bases present in the rain is much pronounced in Djougou region than in the region Lamto. Numerous studies in different parts of the world have shown a strong impact of alkaline soil dust on rainwater composition [47], [50-52].

At the end of this paragraph, it is interesting to note that the partial pressures of FA and AA determined in the atmosphere of our two study sites are in the range of values
( 0.1 to $5.6 \mathrm{ppbv}$ For FA and 0.1 to $2.2 \mathrm{ppbv}$ for $\mathrm{AA}$ ) generally observed in the atmosphere of rural areas[2, 25].

\subsection{Seasonal Evolution of the Partial Pressures of FA and AA}

$\mathrm{P}_{\text {gaz }}$ values of FA and AA were classified into two groups according to the two (02) main seasons (dry season and wet season) of the study period (Figure 4). About, Lamto, values of the partial pressures of FA and AA in the dry season are an average of two (02) times higher than those of the wet season whatever the year. These values vary for formic acid of 0.18 ppbv (2007) to 0.38ppbv (2009) in the dry season and $0.08 \mathrm{ppbv}$ (2005) to $0.15 \mathrm{ppbv}$ (2009) in the wet season. For acetic acid, they oscillate $0.57 \mathrm{ppbv}$ (2007) to $1.07 \mathrm{ppbv}$ (2009) in the dry season and 0.38ppbv (2007) to 0.66ppbv (2006) in the wet season. Contrary to Lamto, the partial pressures of organic acid in the wet season in Djougou not all lower than in the dry season. The observations show that for the first two years (2005 and 2006), the partial pressures of FA and AA in the wet season are on average 1.5 times higher than those of the dry season. And for the last three years of our study period the opposite occurs with an average factor of 3 . The seasonal values of $\mathrm{P}_{\mathrm{gaz}}$ of FA and AA at Djougou vary as well, from 0.04 (2007) $0.21 \mathrm{ppbv}$ (2009) for FA and 0.1 (2005) $0.78 \mathrm{ppb}$ (2009) for the AA in the dry season. In the wet season, they are between 0.007 (2007) and $0.21 \mathrm{ppbv}$ (2005) for FA and 0.03 (2007) to $0.54 \mathrm{ppbv}$ (2006) for AA.

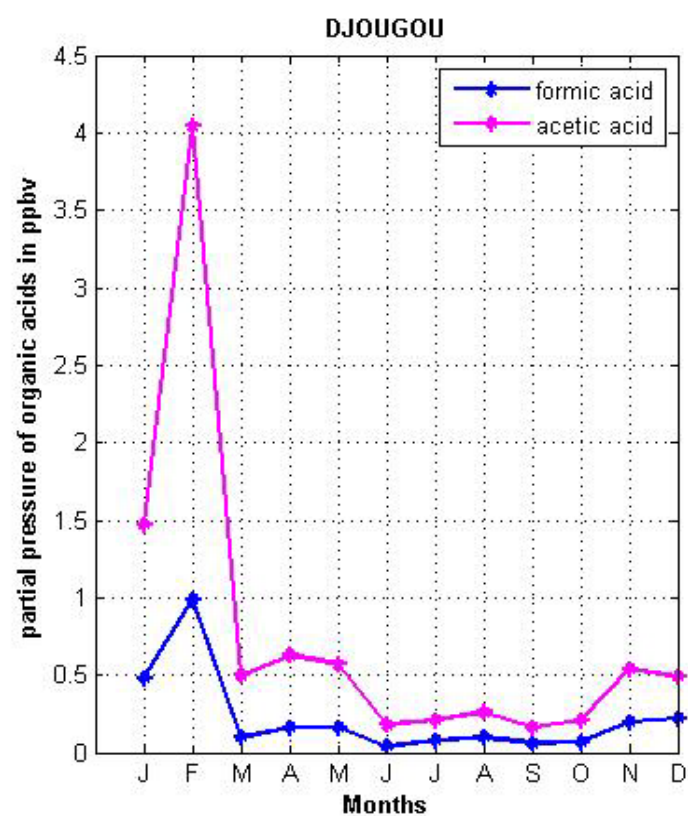

Figure 4. Annual distribution of partial pressures of formic acid and acetic acid in Lanto and in Djougou 
Increased acid levels observed dry season is a feature of our study sites that is to say a common phenomenon. Indeed, like our work, many studies on air pollution and the physical chemistry of rainfall in different African ecosystems have showed an increase in the dry season of two (02) or three (03) times the levels of pollutants such as tropospheric ozone, aerosols and nitrogen compounds[42, 44, 58, 59]. The seasonal variation of organic is not only due to the difference in rainfall between the two seasons. But it would also be linked to the contribution of different sources with predominance due to climatologically and meteorological conditions [25].

The enrichment of the FA and AA contents in the dry season is due to the intensification of inputs from the different sources mainly from the source of biomass burning $[25,39,41,42]$. Indeed, during this season the arid climatic conditions favor the proliferation of biomass burning consequently the intensification of the atmospheric contributions of this source. According to Toure et al. [25] the contribution of this source to the content of formic acid and acetic acid emitted into the atmosphere increases by more than $20 \%$ from the humid season to the dry season. In addition, similar studies of fire aerosols and black carbon (excellent biomass burning markers) have shown that the very high peaks of these compounds in the atmosphere of northern tropical Africa, particularly in the West African region were registered during the dry season.

Concerning the case of the first two years of Djougou where dry season values are lower than those of the humid season, the explanation may be related to a decrease in fire activity due to a less arid dry season. Indeed, for a relatively humid dry season, the contribution of biomass burning to the emission of these two acids decreases. On the other hand, the process of neutralization of acids by the very alkaline dust of the Sahara desert can also provide an explanation for this phenomenon.

Ultimately, it is interesting to note that the seasonal values of the partial pressures of formic acid and acetic acid in the boundary layer of the humid savannah of Lamto have small variations in a given season. Indeed, we have in the dry season for FA and AA, respectively coefficient of variation equal to $26.9 \%$ and $19.3 \%$. In the wet season it is equal to $22.5 \%$ FA and 20\% AA. Therefore, in Djougou seasonal partial pressures, FA and AA present strong variations. So that in the dry season, the coefficient of variation of $73 \%$ and $71.9 \%$ respectively for FA and AA. And humid season, it is equal to $85 \%$ FA and $83.8 \%$ for AA. Thus, we can say that Djougou seasonal contribution of different sources of acids on our period of study is not homogeneous, while the Lamto's is substantially.

\subsection{Annual Distribution of Partial Pressures of FA and}

\section{AA}

$\mathrm{P}_{\mathrm{gaz}}$ values of FA and AA were sorted by month. Monthly averages calculated over the period of five $(05)$ years to determine the average trend of the major organic acids in the boundary layer of the atmosphere humid savannah of Lamto and Djougou over a year. A Lamto the $\mathrm{P}_{\mathrm{gaz}}$ cover a range of highly variable value. The values obtained ranged from 0.05 $\mathrm{ppb}$ (June) $0.54 \mathrm{ppbv}$ (January) to formic acid and $0.26 \mathrm{ppbv}$ (January), $1.62 \mathrm{ppbv}$ (January) to AA. Partial pressures average AA are a 4 times higher than FA. Figure 4a shows the monthly evolution of both FA and AA. It shows a similar trend for both acids with minimal observed in June and two main maxima respectively in December and January. The observed maxima are pronounced. In addition to Djougou values $\mathrm{P}_{\mathrm{gaz}}$ also vary. They vary from $0.04 \mathrm{ppbv}$ to $0.99 \mathrm{ppbv}$ and $0.16 \mathrm{ppbv}$ to $4.04 \mathrm{ppbv}$ respectively for FA and AA. The partial pressures of AA are averaged by a factor 3.3 higher than that of FA. Like Lamto, the monthly evolution of both organic acids Djougou, present similar trends (Figure 4). However, the peculiarities are observed. And the minimum is recorded from the FA $\mathrm{P}_{\mathrm{gaz}}$ in June while the AA is obtained in September. The maximums very pronounced than those Lamto are observed in February. This distribution of partial pressures is therefore linked to non-homogeneous nature of the contribution of sources short of a year. Indeed, in the course of a year climate conditions change from one month to another. Thus, during the usually dry months from December to March in West Africa, lights source dominates contributions, and during the wet months given the low availability of dry plant material down the contribution of biomass burning.

The observed peaks could be linked to the intensification of the acid inputs from the sources of biomass burning. Indeed, many studies on atmospheric pollution in northern tropical Africa during the dry season (from October to December in a current year and January to March of the next year) showed a strong relationship between biomass burning and the peaks of several pollutants such as ozone and black carbon [58]. In addition, the spatializing of fires in West Africa has also revealed that the maximum area burned is not homogeneous and changes according to the month and the regions [60]. Thus, the maximum of biomass burning in the region of Djougou could be observed in February in which the peaks of acid are also observed. Nevertheless, in Lamto these two peaks could be explained by the intensification of the local fire source for the first peak and the other one, the contribution of the source is due to a distant fire created by the effect of the prevailing winds specially Harmattan [25]. The practice of early fires and late fires is an important factor to explain these two peaks observed in Lamto. Thus, this practice is very common in Cote d'Ivoire precisely the savannah area for the hunting and the preparation of cultivable fields [61]. Then, the peak of December could be due to the early fires and the second one of February the late fires.

\section{Conclusions}

Although, our two study sites have some similarities (FA 
and AA emission sources and general climatic characteristics), this study showed very large differences in the variability of the levels of FA and AA. At Lamto, the coefficients of variations at the inter-annual and seasonal scales are relatively low (18-28\%) in contrast to Djougou, where the coefficients are very high $(50-80 \%)$. This difference is attributable to the large variation in the contribution of the sources of aids to Djougou and to the microclimatic differences between the two stations.

Finally, this study deserves to be further studied in order to evaluate the contribution of major sources and the impact of certain microclimatic parameters (wind speed, evaporation etc.). Furthermore, it would be interesting to spread this study at other ecosystems of Africa (arid savannah and forest). The results thus obtained will allow not only understanding the variation and the distribution of theses in tropical Africa atmosphere. But they will be able to be used in calibration atmospheric chemistry models usually at local and regional scales or for developing adapted new models to African continent atmosphere realities.

\section{REFERENCES}

[1] W. C. Keene and J. N. Galloway (1988) The biogeochemical cycling of formic and acetic acids through the troposphere: An overview of current understanding. Tellus, 40 B, 322-334.

[2] P. Khare, G.S. Satsangi, N. Kumar, K.M. Kumari, S.S. Srivastava, 1997. $\mathrm{HCHO}, \mathrm{HCOOH}$ and $\mathrm{CH} 3 \mathrm{COOH}$ in air and rainwater at a rural tropical site in northern central India. Atmospheric Environment 31, 3867-3875.

[3] M. Zhaoyue, J. H. Seinfeld and P. Saxena.(1995) Gas/Aerosol Distribution of Formic and Acetic Acids, Aerosol Science and Technology, 23:4, 561-578,

DOI: $10.1080 / 02786829508965338$

http://dx.doi.org/10.1080/02786829508965338

[4] U. Kuhn, S. Rottenberger, T. Biesenthal, C. Ammann, A. Wolf, G. Schebeske, S. T. Oliva, T. M Tavares. and J. Kesselmeier, (2002) Exchange of short-chain monocarboxylic acids by vegetation at a remote tropical forest site in Amazonia. Journal of Geophysical Research, 107, 8069, doi: 10.1029/2000JD000303.

[5] A. Chebbi and P. Carlier (1996) Carboxylic acids in the troposphere, occurrence, sources, and sinks: A review, Atmospheric Environment, 30, 4233-4249

[6] P. Khare, N. Kumar, K. M. Kumari, and S. S. Srivastava (1999) Atmospheric formic and acetic acids: An overview, Reviews of Geophysics, 37, 227-248.

[7] J. Kesselmeier and M. Staudt (1999) Biogenic Volatile Organic Compounds (VOC): An Overview on Emission, Physiology and Ecology, Journal of Atmospheric Chemistry 33: 23-88, 1999

[8] W. C. Keene, J. N. Galloway, and J. D. Holden, 1983: Measurement of weak organic acidity in precipitation from remote areas of the world, J. Geophys. Res. 88, 5122-5130.
[9] G. E. Likens and J. N Galloway. (1983) The composition and deposition of organic carbon in precipitation, Tellus, 35(B), 16-24.

[10] R. B. Norton, J. M. Roberts, and B. J. Huebert, 1983: Tropospheric oxalate, Geophys. Res. Lett. 10, 517-520.

[11] K., Ng, L. L. Kawamura and I. R. Kaplan: 1985, 'Determination of organic acids $(\mathrm{C} 1-\mathrm{C} 10)$ in the atmosphere, motor exhausts, and engine oils', Environ, Sci. Technol. 19, $1082-1086$

[12] Kawamura, K. and Kaplan, I. R., 1986: Biogenic and anthropogenic organic compounds in rain and snow samples collected in southern California, Atmospheric Environment, 20, 115-124.

[13] M. O. Andreae, R. W. Talbot, and S.-M. Li 1987: Atmospheric measurements of pyruvic and formic acid, Journal of Geophysical Research. 92, 6635-6641.

[14] U. Hofmann, D. Weller, C. Ammann, E. Jork, and J. Kesselmeier, 1997: Cryogenic trapping of atmospheric organic acids under laboratory and field conditions, Atmospheric Environment. 31, 1275-1284.

[15] N. Poisson, M. Kanakidou and P. J Crutzen. (2000) Impact of non-methane hydrocarbons on tropospheric chemistry and oxidizing power of the global troposphere: 3-dimensional modelling results, Journal of Atmospheric Chemistry, 36, $157-230,2000$.

[16] M. Legrand, S. Preunkert, B. Jourdan and B. Aumont (2004) Year-round records of gas and particulate formic and acetic acids in the boundary layer at Dumont d'Urville, coastal Antarctic, J. Geophys. Res., 109, D06313, doi: 10.1029/2003 JD003786, 2004.

[17] R. Zander, P. Duchatelet, E. Mahieu, P. Demoulin, G. Roland, C. Servais, J. V. Auwera2, A. Perrin, C. P. Rinsland, and P. J. Crutzen (2010) Formic acid above the Jungfraujoch during 1985-2007: observed variability, seasonality, but no long-term background evolution. Atmospheric Chemistry and Physics, 10, 10047-10065, www.atmos-chem-phys.net/10/10 047/2010/ doi:10.5194/acp-10-10047-2010

[18] R. Fisseha,, M. Saurer, M. Jaggi, R. T.W. Siegwolf, J. Dommen, S. Szidat., V. Samburova and U Baltensperger. (2009) Determination of primary and secondary sources of organic acids and carbonaceous aerosols using stable carbon isotopes. Atmospheric Environment, 43, 431-437 doi:10.1016/j.atmosenv.2008.08.041.

[19] J. Servant, G. Kouadio, B. Cros. and R. Delmas (1991) Carboxylic Monoacids in the Air of Mayombe Forest(Congo): Role of the Forest as a Source or Sink. Journal of Atmospheric Chemistry, 12, 367-380. http://dx.doi.org/10.10 07/BF00114774

[20] R. J. Yokelson, T. J. Christian, T. G. Karl, and A. Guenther (2008) The tropical forest and fire emissions experiment: laboratory fire measurements and synthesis of campaign data. Atmospheric Chemistry and Physics, 8, 3509-3527. www.at mos-chem-phys.net/8/3509/2008/

[21] T. Stavrakou, J.F. Muller, J. Peeters, A. Razavi, L. Clarisse, C. Clerbaux, P.F Coheur., D. Hurtmans, M. De Maziere, C. Vigouroux, N.M Deutscher., D.W.T. Griffith, N Jones. and C. Paton-Walsh (2012) Satellite Evidence for a Large Source of Formic Acid from Boreal and Tropical Forests. Nature 
Geoscience, 5, 26-30

[22] J. G. Goode, R. J. Yokelson, D. E. Ward, R. A. Sussot, R. E. Babbitt, M. A. Davies and W. M. Hao (2000) Measurements of excess $\mathrm{O}_{3}, \mathrm{CO}_{2}, \mathrm{CO}, \mathrm{CH}_{4}, \mathrm{C}_{2} \mathrm{H}_{4}, \mathrm{C}_{2} \mathrm{H}_{2}, \mathrm{HCN}, \mathrm{NO}, \mathrm{NH}_{3}$, $\mathrm{HCOOH}, \mathrm{CH}_{3} \mathrm{COOH}, \mathrm{HCHO}$ and $\mathrm{CH}_{3} \mathrm{OH}$ in 1997 Alaskan biomass burning plumes by airborne Fourier transform infrared spectroscopy (AFTIR), Journal of Geophysical Research, 105, 22147-22166.

[23] K. Jardine, A. Yañez Serrano, A. Arneth, L. Abrell, A. Jardine, P. Artaxo, E. Alves, J. Kesselmeier, T. Taylor, S. Saleska, and, T. Huxman (2011) Ecosystem-scale compensation points of formic and acetic acid in the central Amazon, Biogeosciences, 8, 3709-3720, doi: 10.5194/bg-8-3709-2011. www.biogeosci ences.net/8/3709/2011/

[24] Akagi, S. K., Yokelson, R. J., Wiedinmyer, C., Alvarado, M. J., Reid, J. S., Karl, T., Crounse, J. D., and Wennberg, P.O. (2011) Emission factors for open and domestic biomass burning for use in atmospheric models, Atmospheric Chemistry and Physics, 11, 4039-4072, doi: 10.5194/acp-11-4039-2011.

[25] P.R. Touré, G.K. Kouadio, U.K. Koffi. and C.R. Beugré (2016) Study of Formic and Acetic Acids in the Air of Humid Savannah Case of Lamto (Cote d'Ivoire). Atmospheric and Climate Sciences, 6, 254-266. http://dx.doi.org/10.4236/acs.2 016.62021

[26] D. J Jacob. and S. C Wofsy. (1988) Photochemistry of biogenic emissions over the Amazon forest, Journal of Geophysical Research, 93, 1477-1486, doi: 10.1029/JD093i D02p01477.

[27] P. Neeb, F. Sauer, O. Horie, and G. K. Moortgat (1997) Formation of hydroxymethylhydroperoxide and formic acid in alkene ozonolysis in the presence of water vapour, Atmos. Environ., 31, 1417-1423,

doi:10.1016/S1352-2310(96)00322-6.

[28] , F. Paulot, D. Wunch, J. D. Crounse, G. C. Toon, D. B. Millet, P. F. De Carlo, C. Vigouroux, N. M. Deutscher, G. Gonzàlez Abad, J. Notholt, T. Warneke, J. W. Hannigan, C. Warneke, J. A. de Gouw, E. J. Dunlea, M. De Mazière, D.W. T. Griffith, P. Bernath, J. L. Jimenez, and, P. O. Wennberg (2011) Importance of secondary sources in the atmospheric budgets of formic and acetic acids, Atmospheric Chemistry and Physics, 11, 1989-2013, doi:10.5194/acp-11-1989-2011.

[29] D. B. Millet, M. Baasandorj, D. K. Farmer, J. A. Thornton, K. Baumann, P. Brophy, S. Chaliyakunnel, J. A. de Gouw, M. Graus, L. Hu, A. Koss, B. H. Lee, F. D. Lopez-Hilfiker, J. A. Neuman, F. Paulot, J. Peischl, I. B. Pollack, T. B. Ryerson, C. Warneke, B. J. Williams, and J. Xu (2015) A large and ubiquitous source of atmospheric formic acid, Atmos. Chem. Phys., 15, 6283-6304, www.atmos-chem-phys.net/15/6283/2 015/ doi:10.5194/acp-15-6283-2015.

[30] B. Yuan, P. R. Veres, C. Warneke, J. M. Roberts, J. B. Gilman, A. Koss, P. M. Edwards, M, Graus., W. C. Kuster, S.-M. Li, R. J. Wild, S. S. Brown, W. P. Dubé, B. M. Lerner, E. J. Williams, J. E. Johnson, P. K. Quinn, T. S. Bates, B. Lefer, P. L. Hayes, J. L. Jimenez, R. J. Weber, R. Zamora, B. Ervens, D. B. Millet, B. Rappenglück, and J. A. De Gouw (2015) Investigation of secondary formation of formic acid: urban environment vs. oil and gas producing region. Atmospheric

Chemistry and Physics, 15, 1975-1993,www.atmos-chem-ph ys.net/15/1975/2015/doi:10.5194/acp-15-1975-2015

[31] E. D. Baboukas, M. Kanakidou, and N. Mihalopoulos (2000)
Carboxylic acids in gas and particulate phase above the Atlantic Ocean, Journal of Geophysical Research 105, 1445914472, doi:10.1029/1999JD900977.

[32] A. L. de Carvalho, E. A. Cardoso, G. O. da Rocha, L. S.G. Teixeira, I. M. Pepe, D. M. Grosjean. (2016) Carboxylic acid emissions from soybean biodiesel oxidation in the EN14112 (Rancimat) stability test. Fuel, 29-36. doi:10.1016/j.fuel.201 5.12 .067

[33] [28] Keene W.C., et al. (1989) An Intercomparison of Measurement Systems of Vapour and Particulate Phase Concentrations of Formic and Acetic Acids. Journal of Geophysical Research: Atmospheres, 94, 6457-6471. http://dx.doi.org/10.1029/JD094iD05p06457

[34] [29] Talbot, R.W., Andreae, M.O., Berresheim, H., Jacob, D.J. and Beecher, K.M. (1990) Source and Sinks of Formic, Acetic and Pyruvic Acids over Central Amazonia 2. Wet Season. Journal of Geophysical Research: Atmospheres, 95, 799-811. http://dx.doi.org/10.1029/JD095iD10p16799

[35] [30] Talbot, R.W., Dibb, J.E., Scheuer, E.M., Blake, D.R., Blake, N.J., Gregory, G.L., Sachse, G.W., Bradshaw, J.D., Sandholm, S.T. and Singh, H.B (1999) Influence of Biomass Combustion Emissions on the Distribution of Acidic Trace Gases over the Southern Pacific Basin during Austral Springtime. Journal of Geophysical Research: Atmospheres, 104, 5623-5634.

[36] [31] Rinsland, C.P., Mahieu, E., Zander, R., Goldman, A., Wood, S. and Chiou, L. (2004) Free Tropospheric Measurem ents of Formic Acid (HCOOH) from Infrared Ground-Based Solar Absorption Spectra: Retrieval Approach, Evidence for a Seasonal Cycle, and Comparison with Model Calculations. Journal of Geophysical Research: Atmospheres, 109, D18308. http://dx.doi.org/10.1029/2004jd004917

[37] [32] R.J. Yokelson, Goode, J.G., Ward, D.E., Susott, R.A., Babbitt, R.E., Wade, D.D., Bertschi, I., Griffith, D.W.T. and Hao, W.M. (1999) Emissions of Formaldehyde, Acetic Acid, Methanol, and Other Trace Gases from Biomass Fires in North Carolina Measured by Airborne Fourier Transform Infrared Spectroscopy. Journal of Geophysical Research: Atmospheres, 104, 30109-30125.

[38] [34] S.C. Herndon, Zahniser, M.S., Nelson Jr., D.D., Shorter, J., McManus, J.B., Jimenez, R., Warneke, C. and de Gouw, J.A. (2007) Airborne Measurements of $\mathrm{HCHO}$ and $\mathrm{HCOOH}$ during the New England Air Quality Study 2004 Using a Pulsed Quantum Cascade Laser Spectrometer. Journal of Geophysical Research: Atmospheres, 112, Article ID: D10S03.

[39] K. G. Kouadio, (1991) Etude de l'origine des acides organiques dans l'atmosphère d'une forêt équatoriale de Mayombe (Congo). Thèse de Doctorat Université Paul Sabatier de Toulouse.

[40] L. Sigha-Nkamdjou, C Galy-lacaux., V. Pont, S. Richard, D. Sighomnou, and, J. P. Lacaux (2003) Rainwater Chemistry and Wet Deposition over the Equatorial Forested Ecosystem of Zoétélé (Cameroon) Journal of Atmospheric Chemistry,46, 173-198

[41] V. Yoboué, C. Galy-Lacaux, J.P. Lacaux and S. Silué (2005) Rainwater Chemistry and Wet Deposition over the WetSavanna Ecosystem of Lamto (Côte d'Ivoire). Journal of Atmospheric Chemistry, 52, 117-141. 
[42] Akpo, A.B., Galy-Lacaux, C., Laouali, D., Delon, C., Liousse, C., Adon, M., Gardrat, E., Mariscal, A. and Darakpa, C. (2015) Precipitation Chemistry and Wet Deposition in a Remote Wet Savanna Site in West Africa: Djougou (Benin). Atmospheric Environment, 115, 110-123.

[43] P. Mayaux, E.E. Bartholome, S. Fritz, A. Belward, 2004. A new land-cover map of Africa for the year 2000. J. Biogeogr. $31,861 \mathrm{e} 877$.

[44] A. M. Adon (2011) Etude des concentrations de gaz atmosphériques et estimation des flux de dépôt Sec à l'échelle des principaux écosystèmes africains. Thèse Université Paul Sabatier de Toulouse et Université d'Abidjan-Cocody

[45] V. Yoboué, K. G. Kouadio, S. Silué and D. Kouamé (2003) Etude de la chimie des pluies dans la savane humide de Lamto; Cote d'Ivoire. Journal de la société Ouest-Africaine de chimie, $15,79-96$.

[46] Lebel, T., Parker, D., Bourles, B., Flamant, C., Marticorena, B., Peugeot, C., Gaye, A.,Haywood, J., Mougin, E., Polcher, J., Redelsperger, J.-L., Thorncroft, C.D., 2009. The AMMA field campaigns: multiscale and multidisciplinary observations in the West African region. Q. J. R. Meteorol. Soc.

[47] B. Sultan and S Janicot, Abrupt shift of the ITCZ over West Africa and intra-seasonal variability. Geophysical Research Letters (2000), vol. 27, no. 20, pp. 3353-3356.

[48] J.N. Mphepya, J.J. Pienaar, C. Galy-Lacaux, G. Held and, C.R. Turner (2004) Precipitation Chemistry in Semi-Arid Areas of Southern Africa: A Case Study of a Rural and an Industrial Site. Journal of AtmosphericChemistry, 47, 1-24.

[49] C. Galy-Lacaux and A.I. Modi (1998), Precipitation chemistry in Sahelian savanna of Niger, Africa, J. Atm. Chem. 30, 319-343.

[50] B.J. Johnson, E.A. Belterton and D. Craig (1996) Henry's Law Coefficients of Formic and Acetic Acids. Journal of Atmospheric Chemistry, 24, 113-119.http://dx.doi.org/10.100 7/BF00162406

[51] A. I. Modi, J.P. Lacaux, L. Labroue and J-G. R. Baudet 1995 : Chimie des aérosols et des pluies dans la savane semi aride du Niger pendant la saison humide de 1989, sécheresse, 6, 331-5

[52] R.E. Ramírez Lara, M. Guardiola, ,Y. G. Vásquez, I. B. Rentería, H. B. Álvarez, R. S. Echeverría, P. S. Álvarez, A. A.
Jiménez, M. C. Torres and J. Kahl (2010) Chemical composition of rainwater in northeastern México. Atmósfera 23(3), 213-224

[53] , Y. C. Mfopou-Mewouo, J.R. N. Ngoupayou, M. Yemefack and V. Agoume (2009) Physico-chimie des pluies du sud Cameroun forestier, Tropicultura, 27, 4, 239-245

[54] Galy-Lacaux C., D. Laouali, L. Descroix, N. Gobron, and C. Liousse (2008) Long term precipitation chemistry and wet deposition in a remote dry savanna site in Africa (Niger). Atmospheric Chemistry and Physics Discussion, 8, 5761-5812, www.atmos-chem-phys-discuss.net/8/5761/2008/

[55] L.T. Khemani, G.A. Momin, P.S, Prakasa Rao, P.D. Safai, G. Singh, R.N. Chatterjee and P. Prakash, 1989. Long-term effects of pollutants on $\mathrm{pH}$ of rain water in North India. Atmospheric Environment 23 (4), 753-756.

[56] A. Saxena., U.C. Kulshrestha. N. Kumar, K.M. Kumari and S.S. Srivastava, 1996. Characterization of precipitation at Agra. Atmos. Environ. 30 (20), 3405-3412.

[57] P.C. Mouli, S.V. Mohan, S.J. Reddy, 2005. Rainwater chemistry at a regional representative urban site: influence of terrestrial sources on ionic composition. Atmospheric Environment 39, 999-1008.

[58] C. Liousse, B. Guillaume, J. M Gregoire, M. Mallet, C. Galy, V. Pont, A. Akpo, M. Bedou, P. Castera, L. Dungall, E. Gardrat, C. Granier, A. Konare, F. Malavelle, A. Mariscal, A. Mieville, R. Rosset, D. Serca, F. Solmon, F. Tummon, E.-M. Assamoi, V. Yoboue, and P. Van Velthoven.: Updated African biomass burning emission inventories in the frame of the AMMA-IDAF program, with an evaluation of combustion aerosols, Atmos. Chem. Phys., 10(3), 7347-7382, 2010.

[59] M. Saunois (2009) Bilan De L'ozone Troposphérique Sur Le Continent Africain : Apport Du Programme Amma-Chimie Thèse Université Toulouse III - Paul Sabatier

[60] E. T. N'Datchoh, A. Konaré, A. Diedhiou, A. Diawara, E. Quansah, and P. Assamoi (2015) Effects of climate variability on savannah fire regimes in West Africa, Earth System Dynamics, 6, 161-174, www.earth-syst-dynam.net/6/161/201 5/ doi:10.5194/esd-6-161-2015

[61] H. Dolidon (2007), La multiplicité des échelles dans l'analyse d'un phénomène d'interface nature/ société. L'exemple des feux de brousse en Afrique de l'Ouest. Environnement, Nature, Paysage, 363. 